Biocontrol Science, 1997, Vol. 2, No. 1, 31-34

Note

\title{
Bactericidal Actions of Hen Egg White Lysozyme and Mutanolysin Against Lactic Acid Bacteria
}

\author{
OSAMU KOBAYASHI*, YOSHIRO HATANAKA, MASATAKA HIGASHIHARA, \\ AND KEIICHIRO HIYAMA
}

Osaka Municipal Technical Research Institute, 1-6-50 Morinomiya, Joto-ku, Osaka 536, Japan

Received 4 September 1996/Accepted 28 November 1996

\begin{abstract}
Hen egg white lysozyme was more effective than mutanolysin in killing lactic acid bacteria. The lysozyme-reated cell suspension had relatively high levels of turbidity but a low viability. On the other hand, the mutanolysin-reated cell suspension showed rather low levels of turbidity but a high cell survival number. Observations using a scanning electron microscope also showed differences in the appearances of the cells damaged by the treatment with each enzyme. The modes of action of the lysozyme and mutanolysin against the cell wall of lactic acid bacteria appeared to be quite different from each other though these enzymes are both a kind of peptidoglycan $\mathbf{N}$-acetylmuramoylhydrolase. From these facts, it was found that for the killing of lactic acid bacteria, lysozyme is more effective than mutanolysin and the simultaneous use of both enzymes is much more effective than the use of a single type of enzyme.
\end{abstract}

Key words : Lysozyme/Mutanolysin/Lytic action/Bactericidal action/Lactic acid bacteria.

Hen egg white lysozyme, a well-known lytic enzyme, is widely used as a disinfectant in medicine. Mutanolysin which, like lysozyme, is a kind of peptidoglycan $\mathrm{N}$-acetylmuramoylhydrolase (E.C. 3.2.1.17), has higher lytic activity against lactic acid bacteria than lysozyme (Yokogawa et al., 1975). However, we reported that the simultaneous use of lysozyme and mutanolysin shows synergistic effects on the lytic action and greater effectiveness in promoting protoplast formation (Kobayashi and Hiyama, 1991; Kobayashi and Hiyama, 1994; Kobayashi and Hiyama, 1995). Therefore, the combination of these enzymes was thought to contribute to the killing of bacteria. Lactic acid bacteria are generally useful microorganisms but the contamination by such a bacteria and their extreme growth lead to the deterioration of the quality of food. In this study, we will describe the bactericidal activities of both enzymes against several kinds of lactic acid bacteria.

The strains of lactic acid bacteria used in this study were Streptococcus bovis IFO 12058, S. bovis ATCC 9809, Lactococcus lactis subsp. lactis ATCC 11454 ,

*Corresponding author. Tel: +81-6-963-8065, Fax : +816-963-8079.
Lc. lactis ATCC 21053, Enterococcus faecalis AHU 1256, Lactobacillus delbrueckii subsp. delbrueckii IFO 3534, Lb. plantarum ATCC 10012, and Lb. brevis AHU 1508. The cells of the lactic acid bacteria were cultured overnight at $30^{\circ} \mathrm{C}$ in the basal culture medium (Kobayashi and Hiyama, 1994), harvested by centrifugation, washed twice with $20 \mathrm{mM}$ Tris- $\mathrm{HCl}$ buffer $(\mathrm{pH} 7.2)$, and resuspended with an equal volume of Tris- $\mathrm{HCl}$ buffer, or directly diluted with Tris- $\mathrm{HCl}$ buffer until the cell concentrations was adjusted to approximately $10^{5} \mathrm{CFU} / \mathrm{ml}$. The specific activities of the hen egg white lysozyme (Sigma Chemical Co.) and mutanolysin ( $N$-acetylmuramidase SG, Seikagaku Kogyo Co., Ltd.) used in the experiments were 230,000 and 20,000 units/mg, respectively. Here, one unit is defined as the enzyme activity which decreases the absorbance at $660 \mathrm{~nm}$ (light path $=1 \mathrm{~cm}$ ) of a suspension of Micrococcus luteus IAM 1056 cells by 0.001 per min at $37^{\circ} \mathrm{C}$ in Tris- $\mathrm{HCl}$ buffer. After the addition of the lysozyme and/or mutanolysin, the cell suspension was incubated at $37^{\circ} \mathrm{C}$ for $2 \mathrm{~h}$ with shaking. The cells that survived were then measured by the agar plate dilution method using the basal culture medium containing $1.5 \%(\mathrm{w} / \mathrm{v})$ agar. During the incubation of untreated cells without enzymes, the 
TABLE 1 . Bactericidal activities of lysozyme and mutanolysin against several kinds of lactic acid bacteria.

\begin{tabular}{|c|c|c|c|}
\hline \multirow{2}{*}{ Strain } & \multicolumn{2}{|c|}{ Concentration $^{a}(\mu \mathrm{g} / \mathrm{ml})$} & \multirow{2}{*}{$\begin{array}{c}\text { Survivors } \\
(\%)\end{array}$} \\
\hline & Lysozyme & Mutanolysin & \\
\hline \multirow[t]{4}{*}{ S. bovis IFO 12058} & 0.4 & 0 & 1.4 \\
\hline & 4 & 0 & $<0.01$ \\
\hline & 0 & 20 & 9.5 \\
\hline & 0.4 & 20 & $<0.01$ \\
\hline \multirow[t]{6}{*}{ S. bovis ATCC 9809} & 0.4 & 0 & 11 \\
\hline & 4 & 0 & 0.10 \\
\hline & 0 & 2 & 4.1 \\
\hline & 0 & 20 & 0.01 \\
\hline & 0.4 & 2 & 0.13 \\
\hline & 0.4 & 20 & $<0.01$ \\
\hline \multirow[t]{5}{*}{ Lc. lactis ATCC 11454} & 0.4 & 0 & 11 \\
\hline & 4 & 0 & $<0.01$ \\
\hline & 0 & 2 & 15 \\
\hline & 0 & 20 & 0.38 \\
\hline & 0.4 & 2 & $<0.01$ \\
\hline \multirow[t]{4}{*}{ Lc. lactis ATCC 21053} & 0.4 & 0 & 0.37 \\
\hline & 4 & 0 & $<0.01$ \\
\hline & 0 & 20 & 4.2 \\
\hline & 0.4 & 20 & $<0.01$ \\
\hline \multirow[t]{4}{*}{ E. faecalis AHU 1256} & 0.4 & 0 & 4.6 \\
\hline & 4 & 0 & $<0.03$ \\
\hline & 0 & 20 & 77 \\
\hline & 0.4 & 20 & 1.8 \\
\hline \multirow[t]{4}{*}{ Lb. delbrueckii IFO 3534} & 0.1 & 0 & 0.19 \\
\hline & 4 & 0 & $<0.02$ \\
\hline & 0 & 20 & 79 \\
\hline & 0.1 & 20 & $<0.02$ \\
\hline \multirow[t]{4}{*}{ Lb. plantarum ATCC 10012} & 4 & 0 & 0.33 \\
\hline & 40 & 0 & 0.08 \\
\hline & 0 & 2 & 3.1 \\
\hline & 0 & 20 & 0.54 \\
\hline \multirow[t]{5}{*}{ Lb. brevis AHU 1508} & 4 & 2 & $<0.01$ \\
\hline & 0.4 & 0 & 0.16 \\
\hline & 4 & 0 & $<0.01$ \\
\hline & 0 & 20 & 63 \\
\hline & 0.4 & 20 & $<0.01$ \\
\hline
\end{tabular}

${ }^{a}$ Final enzyme concentration in the reaction mixture.

${ }^{b}$ Survivors in the untreated cell suspension (about $10^{5} / \mathrm{ml}$ ) was $100 \%$.

survivors slightly decreased by $0-20 \%$.

As shown in Table 1, lysozyme was generally more effective than mutanolysin in killing lactic acid bacteria. However, the sensitivity to lytic enzymes was quite different among the strains. Mutanolysin $(20 \mu$ $\mathrm{g} / \mathrm{ml}$ ) had little bactericidal effect on $E$. faecalis AHU 1256, $L$ b. delbrueckii IFO 3534, and $L b$. brevis AHU 1508. However, some bactericidal effect was seen against S. bovis ATCC 9809, Lc. lactis ATCC 11454 , and $L$ b. plantarum ATCC 10012 with a lower concentration of mutanolysin $(2 \mu \mathrm{g} / \mathrm{ml})$. In our previous reports (Kobayashi and Hiyama, 1991; Kobayashi and Hiyama, 1994; Kobayashi and Hiyama, 1995), some strains used in this experiment, e.g., S. bovis IFO 12058, were lysed more effectively by mutanolysin than by lysozyme when monitoring the absorbance decrease at $660 \mathrm{~nm}$. Since the lysozyme was more effective than mutanolysin in the killing of $10^{5} \mathrm{CFU} / \mathrm{ml}$ cells (Table 1), the absorbance at 660 $\mathrm{nm}$ and the viability was measured after cells of $S$. 
TABLE 2. Bactericidal effects of lysozyme and mutanolysin against $S$. bovis IFO 12058 and the decrease in absorbance of the cell suspension.

\begin{tabular}{lccc}
\hline Enzyme & $\begin{array}{c}\text { Concentration } \\
(\mu \mathrm{g} / \mathrm{ml})^{a}\end{array}$ & $\begin{array}{c}\text { Absorbance } \\
\text { at } 660 \mathrm{~nm}^{b}\end{array}$ & $\begin{array}{c}\text { Number of } \\
\text { surviving cells } \\
(/ \mathrm{ml})\end{array}$ \\
\hline None & - & 0.348 & $4.1 \times 10^{7}$ \\
Lysozyme & 40 & 0.285 & $2.2 \times 10^{4}$ \\
Mutanolysin & 20 & 0.090 & $1.3 \times 10^{7}$ \\
\hline
\end{tabular}

${ }^{a}$ Final enzyme concentration in the reaction mixture.

${ }^{b}$ Measured after $2 \mathrm{~h}$ incubation at $37^{\circ} \mathrm{C}$.

bovis IFO 12058 at higher concentrations was washed and then treated with each lytic enzyme. As shown in Table 2, there is no significant relation between the absor-bance and the viability of after the action of lysozyme and that of mutanolysin. The lysozyme-treated cell suspension showed a relatively higher absorbance but a lower viability. On the other hand, the mutanolysin-treated cell suspension showed a rather lower absorbance but a higher viabil- ity. The features of each type of cells treated with the enzyme were then observed with a scanning electron microscope. As shown in Fig. 1, the untreated cell shows a smooth surface but the cell treated with lysozyme has deep clefts, and there are small particles, which might be fragments derived from the cell wall, around the cell. However, after the mutanolysin treatment, the cells do not have deep clefts on the surface but larger amounts of small particles can be
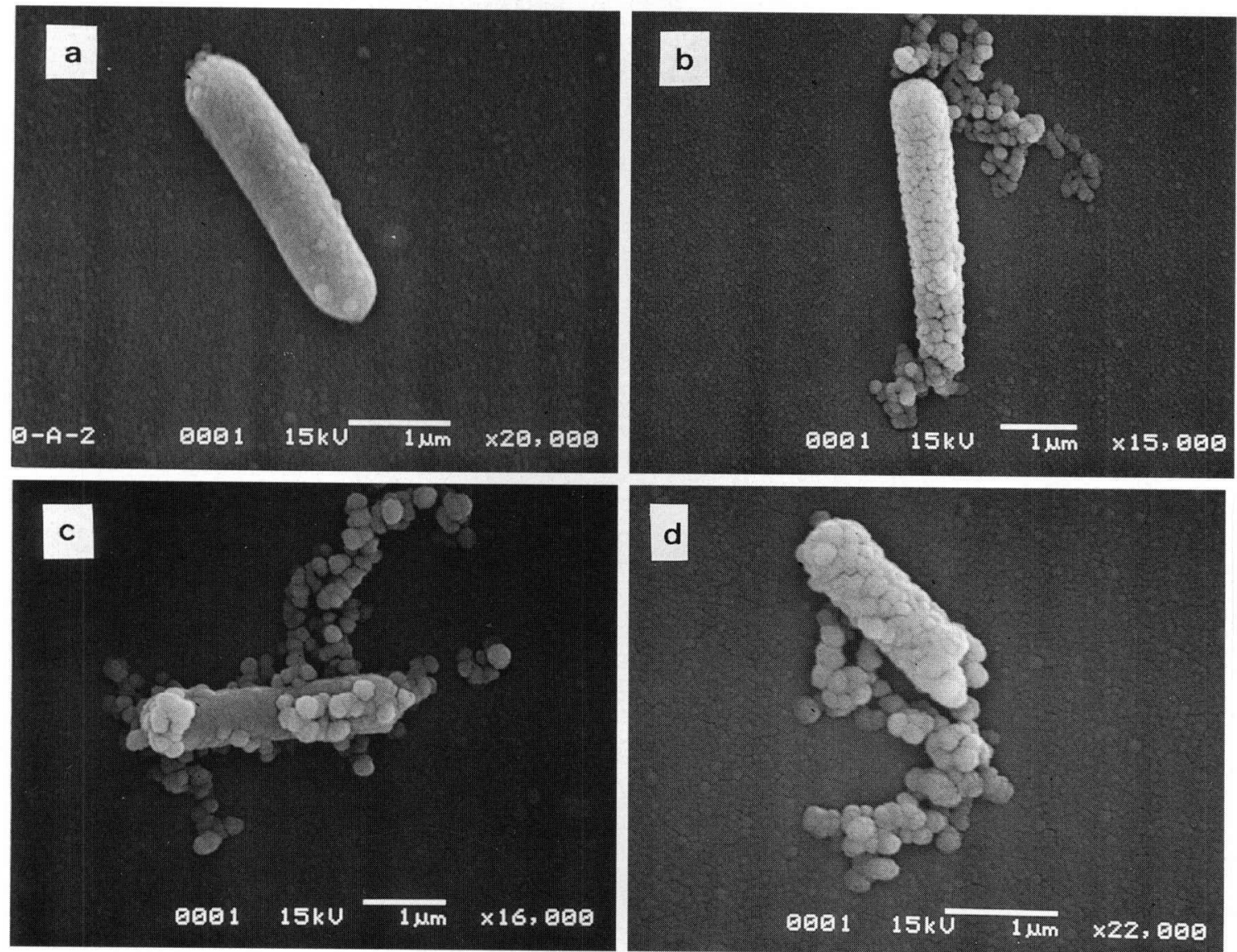

FIG. 1. Scanning electron microscopic features of the untreated cell (a), lysozyme-treated cell (b), mutanolysin-treated cell (c), and the cell treated with both enzymes (d) in the case of $L b$. plantarum ATCC 10012 . The enzyme treatment was doen with 45 min incubation at $37^{\circ} \mathrm{C}$. 
observed around the cell. Furthermore, as shown in Table 1, the synergistic effect of the simultaneous use of lysozyme and mutanolysin can be observed in terms of the bactericidal as well as the lytic activity monitored by decreasing absorbance (Kobayashi and Hiyama, 1991; Kobayashi and Hiyama, 1994; Kobayashi and Hiyama, 1995).

From the differences in the lytic action and bactericidal activity and the observations by scanning electron microscopy, it may be concluded while lysozyme and mutanolysin are both a peptidoglycan $\mathrm{N}$ acetylmuramoylhydrolase, they are quite different from each other in the mode of action against the cell wall of lactic acid bacteria. Namely, it seems that lysozyme may penetrate the cell wall at narrow regions resulting in the appearance of clefts, and the bacteria are killed with few changes in turbidity. On the other hand, mutanolysin may act to pare away the cell wall layer, so that the cells become like protoplasts, which can regenerate and grow in the medium, and the turbidity of the cell suspension may be decreased. Accordingly, the simultaneous use of the lysozyme and mutanolysin, which can give rise to a synergistic effect, may be applied to the effective killing of a large number of lactic acid bacteria species, especially those that are resistant to the lytic ac- tion of a single kind of enzyme.

\section{ACKNOWLEDGMENTS}

We thank Miss Chikako Sakai and Miss Chikako Yamamoto for their assistance.

\section{REFERENCES}

Kobayashi, O., and Hiyama, K. (1991) Protoplast Formation and Regeneration of Lactic Acid Bacteria (in Japanese). Kagaku To Kogyo (Osaka), 37, 123-128.

Kobayashi, O., and Hiyama, K. (1994) Protoplast Formation and Regeneration of Streptococcus bovis Cells. Biosci. Biotechnol. Biochem., 58, 1886-1888.

Kobayashi, O., and Hiyama, K. (1995) Protoplast Formation and Regeneration of Lactobacillus plantarum (in Japanese). Kagaku To Kogyo (Osaka), 69, 123-125.

Yokogawa, K., Kawata, S., Takemura, T., and Yoshimura Y. (1975) Purification and Properties of Lytic Enzymes from Streptomyces globisporus 1829. Agric. Biol. Chem. 39, 1533-1543. 